\title{
Pengembangan Layanan Pusat Karir sebagai Strategi Membentuk Karakter yang Tangguh dalam Membangun Perencanaan Karir Mahasiswa Di Era Revolusi Industry 4.0.
}

\author{
Ni Gusti Made Rai ${ }^{1}$, Eka Dian Savitri ${ }^{2}$, dan Aurelius Ratu ${ }^{3}$ \\ Program Studi Pembangunan, Fakultas Bisnis Manajemen Teknologi, Institut Teknologi Sepuluh Nopember \\ ni.gusti@its.ac.id
}

\begin{abstract}
ABSTRAK
Pendidikan memiliki tujuan mulia yaitu mencetak generasi tangguh yang berkualitas. Kampus sebagai institusi pendidikan perlu memperhatikan adanya kebutuhan mahasiswa untuk mencapai visi dan misi dari pendidikan. Dalam rangka mempersiapkan diri atas perubahan revolusi industry 4.0 maka pendidikan turut memiliki andil. Pusat karir sebagai salah satu unit pengelolaan mahasiswa di kampus perlu melakukan peningkatan layanan pengelolaan mahasiswa sebagai langkah pengembangan SDM. Pusat karir memiliki tanggung jawab untuk melakukan pengelolaan SDM di kampus akhirnya perlu meningkatkan layanannya. Tidak terbatas pada persoalan link and match perguruan tinggi dan industri sebagai hilir dari proses pendidikan. Tetapi perlu mendesain layanan yang berfokus pada penyelesaian persoalan mahasiswa hingga memiliki kesejahteraan psikologis yang mantap. Dengan demikian harapannya dimiliki corak karakter mahasiswa yang tangguh yaitu siap menghadapi tantangan sebagai permulaan membangun perencanaan karir yang mantap. Model pengembangan layanan pusat karir yaitu hingga menyentuh pada kebutuhan kesejahteraan psikologis yang harus diperhatikan. Fokus pada persoalan akademis dan kognitif mahasiswa merupakan paradigm lama yang harus mulai digeser.
\end{abstract}

Kata kunci : kesejahteraan psikologis mahasiswa, perencanaan karir, pengembangan pusat karir, karakter tangguh

\section{PENDAHULUAN}

\subsection{Latar Belakang}

Model pendidikan saat ini telah berkembang dibandingkan dengan sistem yang terdahulu. Saat ini adanya sistem pendidikan turut berfokus pada masalah empowering of people. Hal ini disebabkan adanya gejala bawa sistem pendidikan terdahulu lebih melihat manusia sebagai obyek pendidikan. Dengan demikian harapannya pendidikan dalam lebih mengembangan pola berpikir masyarakat. Selain itu adanya perubahan dari orientasi pendidikan yaitu pendidikan bermuara pada dunia kerja yang harus didesain sejak awal. Sehingga pendidikan tidak semata-mata berorientasi pada aspek kognitif semata. Namun justru pada hal-hal yang terkait pada kepribadian yaitu berupa unsur afektif dan psikomotor. (Muhson, Wahyuni, \& Mulyani, 2012) . Dengan demikian pendidikan harus berorientasi pada life skill. Lebih lanjut Muhson menjelaskan bahwa pendidikan harus turut mengantarkan anak didiknya untuk mendapatkan kecapakan hidup yang lebih bermakna. Bahkan harus disadari bahwa begitu pentingnya setiap individu memperhatikan kualitas diri melalui kepribadiannya untuk mencapai kesuksesan dimasa mendatang. Hal tersebut menunjukkan adanya unsur penting yang harus dimiliki oleh segenap lingkungan pendidikan termasuk kampus, untuk memperhatikan desain pengembangan mahasiswa sebagai asset sumber daya manusia terutama berkaitan dengan kualitas mental. Pada akhirnya menjadi 
generasi yang tangguh dan andal untuk dapat melihat peluang besar dan mencapai karir yang sukses. Diawali perencanaan karir mahasiswa yang harus didesain baik mencapai kebutuhannya yang bersifat individu.

Perubahan kehidupan yang sangat dinamis ini ternyata juga meningkatkan berbagai persoalan yang semakin kompleks. Termasuk yang berhubungan dengan problem psikologis. Banyak orang berpandangan bahwa kehidupan kampus seolah tidak pernah berhubungan dengan persoalan-persoalan psikologis. Kegiatan di kampus dipandang akan hanya berhubungan dengan aktivitas akademik yang menggugah aspek kognitif. Tetapi ternyata muncul pula persoalan diantara mahasiswa yang justru perlu mendapatkan perhatian serius sebelum mereka berpikir tetang karir. Bahkan penanganan atas problem tersebut membutuhkan proses yang panjang dan melibatkan berbagai pihak karena berhubungan dengan persoalan kepribadian dan kesejahteraan psikologis mahasiswa.

Berdasarkan data di Kementrian Kesehatan Republik Indonesia menunjukkan bahwa sekitar 14 juta masyarakat Indonesia menderita problem psikologi yang berhubungan dengan gangguan emosional, depresi dan kecemasan. Angka kejadiannya bisa mencapai 5,6 persen dari seluruh penduduk. Sedangkan menurut WHO, data global yang ada bahwa sekitar 300 juta orang mengalami depresi. Dan baru sekitar 10 persen yang mendapatkan pelayanan kesehatan karena adanya berbagai keterbatasan. Salah satu persoalan kesehatan mental seperti depresi ini akan berdampak pada penurunan produktifitas seorang manusia. Dan secara ekstreem akan mendorong terjadinya persoalan yang lebih serius seperti percobaan bunuh diri. Menurut WHO setiap tahunnya terdapat sekitar 8000 orang melakukan percobaan bunuh diri. Dan pada kelompok dengan rentang usia 15 sd 29 tahun menjadi penyebab utama kematian. Bahkan Indonesia menduduki peringkat keenam sebagai negara dengan jumlah kasus depresi tertinggi. (Most depressed country). Data yang tertera menunjukkan adanya persoalan serius berkaitan dengan kesejahteraan psikologis yang justru nampak tidak terlihat secara kasat mata ini. Banyak orang pula mengabaikan penanangan pada apalagi dikalangan mahasiswa yang dianggap bebas dari persoalan tersebut karena statusnya sebagai kaum intelektual.

Kesejahteraan psikologis berhubungan erat dengan kualitas kesehatan mental. Dengan kesejateraan psikologi yang kurang akan mempengaruhi kemampuan individu melakukan penyesuaian terhadap persoalan internal (dalam diri) maupun ekternal (berhubungan dengan likungan di sekitarnya). Hal terbebut akan mempengaruhi pengeloaan emosi yang pada akhirnya berperan melakukan keseimbangan dalam kesehatan mental. Kesehatan mental menjadi salah satu faktor utama bagi seorang yang menginginkan memiliki karir sukses dimasa depan. Bahkan tidak dapat dipungkiri dalam suatu proses seleksi karyawan menjadi bagian penting terkait proses evaluasi mengenai kondisi psikologis calon kandidat. Seseorang yang dianggap sehat menurut WHO adalah seorang individu yang memiliki status sehat secara fisik dan mental. Jadi tidak cukup bagi seorang individu untuk memperhatikan dan merawat kondisi fisik saja.

Kampus sebagai lembaga mendidikan tinggi yang memiliki tujuan sesuai arahan Direktorat Jendral Pendidikan Tinggi. Dimana memiliki tujuan untuk menghasilkan lulusan yang berkualitas dan mampu memenuhi pasar kerja. Lulusan tidak hanya perlu menguasai ilmu pengetahuan, teknologi atau seni bidang tertentu, tetapi juga mampu menguasai ketrampilan tambahan seperti berkomunikasi efektif, kemampuan berpikir logis, mampu beradaptasi yang sering disebut sebagai soft skill. Dengan kata lain lulusan diharapkan memiliki corak karakter yang mantap. Karakter yang tangguh akhirnya dianggap sebagai laha satu kompetensi yang perlu dimiliki mahasiswa. Karakter yang tangguh dipengaruhi olehh kualitas kesejahteraan psikologis yang sering dikenal pula dengan istilah kesehatan mental. Namun demikian rasanya harapan mulia tersebut menjadi kontras saat melihat berbagai pemberitaan yang ada 
beberapa waktu terakhir ini. Sedangkan berdasarkan survey awal di PK2M ITS yang pernah dilakukan pada 46 mahasiswa, terdapat $24 \%$ memiliki kecenderungan depresi sedang. Faktor yang menyebabkan terjadinya persoalan kesehatan mental tidak dapat dibatasi hanya dari faktor akademis (contoh, ketidakmampuan diri menyesuaikan tuntutan studi, kesalahan memilih jurusan, persoalan metode pembelajaran yang berbeda dibandingkan SMA, dan sebagainya). Dapat pula disebabkan dari non akademis terkait tekanan sosial (misalnya, persoalan di dalam keluarga, persoalan keuangan keluarga, hubungan pertemanan dari latar belakang sosial dan budaya yang berbeda, dan sebagainya).

Berada diantara mahasiswa yang memiliki padatnya kegiatan agaknya sedikit mengesampingkan adanya pola manajemen diri. Nampaknya perlu menjadi perhatian kita bersama umum membentuk karakter yang tangguh. Karakter yang tangguh akan mengantarkan segenap lulusan untuk siap memasuki jenjang lebih tinggi yaitu sebagai seorang dewasa yang menyiapkan karir suksesnya. Tanpa adanya karakter yang tangguh maka akan sulit memiliki perencanaan karir yang mantap apalagi mencapai karir yang sukses. Sementara ini bahwa kasus-kasus yang membutuhkan pelayanan kesehatan mental dan psikologi ini masih mengalami kesulitan untuk mendapatkan akses yang jelas dan cepat. Beberapa hal diantaranya yaitu pertama, kurangnya sosialisasi kepada mahasiswa untuk mendapatkan pelayanan yang tepat, efektif, dan intensif; Kedua, perhatian pihak-pihak seperti dosen maupun institusi dalam persoalan terkait kesejahteraan psikologis dan karir; Ketiga, keterbatasan SDM khususnya dibidang pelayanan kesehatan mental dan psikologis; Keempat, tidak adanya SOP dalam merujuk Mahasiswa yang membutuhkan pelayanan secara intensif. Hal-hal ini menjadi kurang optimalnya penanganan kasus yang ada. Dengan kualitas kesejahteraan psikologis yang baik maka akan mendukung tercapainya kualitas lulusan.

Perlu adanya pengembangan layanan sebagai bentuk wujud kepedulian pusat karir yang sering kali berhadapan dengan calon lulusan yang ternyata belum siap menghadapi dunia kerja. Lebih lanjut mahasiswa dengan problem psikologis dapat menghambat usaha untuk mencapai keoptimalannya dalam menyelesaikan tugas selama masa studi hingga nantinya mencari peluang yang ada. Lebih lanjut akan ditumui kesulitan menemukan pekerjaan yang cocok dalam waktu yang singkat tentunya akan mempengaruhi masa tunggu kerja. Dan juga menghambat produktifitas lulusan berkarir, hingga kepuasan kerja yang akan dirasakan. Untuk itu diperlukan adanya pengembangan layanan yang menitik beratkan pada penyediaan fasilitas kepada mahasiswa untuk dapat mengkonsultasikan persoalannya, menjacapai kesejahteraan psikologis dan mencapai karakter yang diharapkan. Dan merancang program yang termasuk sebagai upaya promosi akan persiapan dunia kerja dan berhubungan dengan persiapan sehingga terwujud karakter yang tangguh dan siap menghadapi tantangan terutama dalam memasuki revolusi industry 4.0 .

\section{TINJAUAN TEORITIS}

\subsection{Pusat Karir}

Pusat Karir adalah suatu lembaga di dalam struktur perguruan tinggi yang melakukan fungsi mempertemukan mahasiswa dan lulusan pencari kerja dengan pengguna tenaga kerja (perusahaan). Pusat Karir dapat memberikan manfaat kepada perguruan tinggi dan lembaga terkait : a. mengetahui proporsi lulusan yang terlah terserap didunia kerja; b. menyiapkan lulusan dengan kompetensi yang dibutuhkan dan diharapkan industri; c. membantu proses pemerintah dalam memetakan kebutuhan industri dan pembangunan pendidikan di Indonesia (Syafiq, 2018). Pusat karir dengan perannya yang begitu strategis sebagai jembatan atau penghubung perguruan tinggi dan pasar kerja, tetapi juga memiliki tugas untuk meningkatkan kompetensi yang dimiliki oleh lulusan. Bahkan akan memiliki fungsi 
yang lebih baik jika melakukan pembinaan terhadap rencana karir yang dimiliki mahasiswa sejak masuk kuliah ditahun pertama. Contoh kegiatan yang dilakukan oleh pusat karir (Ir. Ahmad Syafiq, MSc et al., 2018), yaitu bahwa pusat karir melakukan :

1. Training atau workshop kepada mahasiswa untuk meningkatkan soft skill

2. Melaksanakan konseling karir

3. Memberikan informasi lowongan pekerjaan

4. Melaksanakan tracer study

Secara umum layanan pusat karir kurang memfasilitasi kebutuhan mahasiswa dalam menuntaskan problem diri untuk mencapai kompetensi diri sebagai skill yang akan mengarahkan pada perencanaan karir yang efektif. Untuk itu perlukan adanya program pengembangan sebagai wujud peningkatan kualitas layanan kepada mahasiswa mencapai karakter tangguh.

\subsection{Karakter Tangguh}

Dalam Kamus Besar Bahasa Indonesia, Karakter merupakan unsur kejiawaan, akhlak, budi pekerti yang membedakan satu orang dengan lainnya. Karakter merupakan ciri karakteristik atau corak yang dimiliki seseorang sebagai aspek kejiawaan yang bersifat unik. Karakter tangguh merupakan karakter yang mampu dengan mantap dan tidak tergoyahkan saat menghadapi beragam tantangan. Karakter tangguh artinya mampu menempa diri saat tekanan bahkan datang melanda dan mampu mencapai solusi yang efektif. Lebih lanjut bahwa karakter tangguh menjadi salah satu aspek yang melekat Individu untuk dapat mengelola kondisi emosionalnya secara proporsional jika berhadapan dengan tekanan lingkungan. Karakter tangguh sebagai salah satu kompentensi yang diharapkan mampu dimiliki setiap lulusan perguruan tinggi. Dengan demikian harapannya kesenjangan yang ada antara lulusan dan dunia industry semakin rendah. Karena industry di era 4.0 secara umum membutuhkan SDM yang mampu menunjukkan kualitas diri melalui corak karakter yang siap menghadapi tantangan.

Model pengembangan diri mahasiswa perlu dibuat sebagai bahan mendesain SDM di kampus dengan harapan mencapai karakter mahasiswa yang diharapkan. Mencapai kualitas yang unggul juga perlu dilihat dari sisi kualitas pribadi yang tangguh. Karakter tangguh berarti juga memiliki ketahanan dalam menghadapi segala tantangan yang beragam yang mungkin menimbulkan gejolak secara emosional. Termasuk dalam menghadapi kesulitan dalam proses perkuliahan hingga beragam aktivitas dalam kehidupan. Seseorang yang mampu dengan mantap menghadapi beragam tantagan juga dianggap mampu melakukan penyesuaian pada periode yang akan ditempuh. Tidak menutup kemungkinan akan dihadapkan suatu peristiwa hidup yang mendatangkan tekanan atau bahkan menjadi kondisi yang stressfull. Tekanan yang berkepanjangan maka akan membuat seseorang merasa beban menjadi lebih berat. Istilah yang disebut suatu kondisi stress maka akan dapat mempengaruhi produktivitas seseorang. Produktivitas yang tidak optimal menjadi persoalan yang cukup diperhatikan. Status sebagai mahasiswa biasanya akan dijumpai persoalan yang berhubungan dengan bidang akademis. Namun jika persoalan menjadi lebih kompleks maka dibutuhkan strategi efektif untuk mengatasinya. Untuk itu perlu adanya upaya untuk meningkatkan kesadaran dan kesiapan dari mahasiswa itu sendiri untuk menjadi lebih adaptif dan matang menghadapi persoalan yang muncul. Tidak menempatkan orang lain ataupun dari berbagai pihak yang bertanggung jawab. Tetapi dikhususkan bagaimana strategi kampus dalam mencapai kualitas mahasiswa yang andal yaitu karakter yang tangguh dalam menghadapi tantangan memasuki era revolusi industry 4.0. 


\subsection{Program Pengembangan layanan Karir Mahasiswa}

Program pengembangan dalam bentuk layanan di pusat karir yang ditujukan oleh seluruh mahasiswa. Penyelesaiaan persoalan dan tercapainya kesejahteraan psikologi merupakan usaha mencapai generasi dengan corak karakter yang tangguh demi mencapai kompetensi lulusan yang dibutuhkan pasar. Pusat karir yang ditunjuk untuk melakukan pengeloaan diharapkan melakukan positioning yang mantap agar keberadaannya turut mencapai target yang diharapkan Dan pada akhirnya mampu mendapatkan dukungan dari berbagai pihak untuk bersama-sama mewujudkan lulusan yang berkarakter tangguh.

Layanan Personal Development \& Care menjadi salah satu bentuk pengembangan dari unit pusat karir menjadi wadah yang memiliki fungsi utama dalam melayani kebutuhan psikologis mahasiswa. Layanan ini dibangun dalam rangka kepedulian kampus terhadap tingkat kesejahteraan psikologis dan mental mahasiswa dalam rangka mempersiapkan generasi dalam memasuki dunia kerja. Kampus pada akhirnya sebagai lingkungan akademis dapat menjadi model (Social Support System) yang kuat untuk mendorong segenap lulusan memiliki ketangguhan dalam menghadapi beragam tantangan mendatang. Mahasiswa perlu medapatkan peningkatan individual wellness. Yaitu upaya meningkatkan kompetensi dan skill dalam membangun startegy coping yang adaptif dalam menghadapi beragam tantangan dalam dunia karir. Contoh: meningkatkan regulasi diri mahasiswa, problem solving, membangun empati, conflict interpersonal, dan seterusnya.

\subsection{Mahasiswa dan ciri karakteritiknya}

Mahasiswa merupakan generasi penerus yang sedang menempuh masa studi di pendidikan tinggi. Mahasiswa secara umum berada pada jenjang usia di periode transisi, yaitu pada masa remaja dan dewasa awal. Berdasarkan usia yang melekat pada mahasiswa tersebut menunjukkan adanya kebutuhan untuk menemukan jati diri. Jati diri perlu untuk dimantapkan untuk mencapai karakteristik diri yang manpa sebagai proses pengembangan diri yang terus berjalan. Mahasiswa yang berkembang dalam situasi yang kurang mantap akan menunjukkan kesulitan dalam memasuki tahapan kehidupan selanjutnya. Dimasa awal perkuliahan mahasiswa dihadapkan adanya transisi kehidupan yang cukup "kritis". Persoalan yang dibawa sejak dini jika tidak terselesaikan dengan baik akan menimbulkan dampak pada tahapan perkembangan berikutnya. Bagi mahasiswa yang telah mendapatkan kesempatan untuk mengasah diri sehingga memiliki pengalaman berharga yang dapat membangun karaktrakter yang tangguh. Tetapi tidak berjalan secara alamiah bahwa setiap individu ini akan mampu mencapai kamatangan yang baik. Perlu perhatian bagi intitusi pendidikan sekalipun untuk turut mendesain kebutuhan perencanaan pengembangan karakter mahasiswa dalam rangka menyiapkan kematangan diri yang prima. Khususnya berdasarkan kebutuhan dalam tugas perkembangan dalam memasuki usia dewasa maka dibutuhkan adanya mekanisme yang memprioritaskan kebutuhan peningkatan softskill mahasiswa. Salah satu aspek yang disoroti terutama dalam mendukung peningkatakn komptensi yang dibutuhkan dunia industry yaitu melakukan sosialisasi program karir mahasiswa itu sendiri. Mahasiswa pada akhirnya diajak untuk berpikir mengembangkan diri secara optimal melalui cara-cara praktis. Pemahaman akan kebutuhan diri mahasiswa perlu ditingkatkan sejak dini untuk mendorong tercapainya perencanaan karir yang mantap. Karena secara teoritis mahasiswa sejak di awal tahun akan melakukan banyak penyesuaian yang bisa mempengaruhinya hingga mengalami suatu tekanan atau stress. Tentunya stress yang tidak tertangani dengan baik akan mempengaruhi produktivitasnya. 


\subsection{Karir dan Perencanaan Karir Mahasiswa}

Karier menurut Kamus Besar Bahasa Indonesia merupakan perkembangan dan kemajuan dalam kehidupan, pekerjaan atau jabatan, pekerjaan yang memberikan harapan untuk maju. Hal ini sejalan dengan karir diungkapkan sebagai bagian dari tugan perkembangan (Santrock), terutama saat telah menuntaskan pada pendidikan tinggi. Perencanaan karir merupakan salah satu aspek penting dalam perkembangan manusia dalam mencapai ksuksesan dalam hidup. Perencanaan karir dianggap sebagai aktivitas yang melibatkan upaya peneropongan ke dalam dan keluar diri. Bahkan adanya hubungan antara karakteritik personal seseorang terhadap karir dimasa depannya (Rogers, Creed, \& Glendon, 2008). Melakukan perencanaan karir merupakan suatu pekerjaan tambahan. Karena diperlukan usaha yang lebih dalam untuk melakukan pemahaman tentang apa yang kemudian akan diputuskan dalam mencapai karir (Evans, 2017). Perencanaan Karir menurut Rivai dalam (Ozora, Suharti, \& Sirine, 2016) merupakan proses individu dalam menyeleksi tujuan dan jenjang karirnya. Hal ini berkaitan dengan bagaimana setiap karakteristik dan dari pekerjaan dinilai dan ditetapkan apakan sesuai dengan apa yang dimiliki. Dalam melakukan perencanaan karir maka akan dimulai dari adanya usaha secara sadar untuk menggali lebih dalam mengenai karakteristik diri yang dimiliki. Dan kemudian selanjutnya melakukan upaya memperkirakan tujuan di masa depan. Evaluasi yang dilakukan yaitu melakukan pencocokan karakteritik yang dimiliki tersebut dan harus bersinergi dengan baik untuk bisa dicapai dalam rangka mendukung target yang ada. Perencanaan karir terkait dalam ilmu psikologi perkembangan melalui tahap tugas perkembangan yang seharusnya dapat dicapai pada rentang usia tertentu. Sesuai dengan teori dari Gizenberg (Ozora, 2016) membagi tahapan karir berdasarkan usia menjadi tiga tahap. Yaitu pertama usia ( 0 - 11 tahun), merupakan tahap fantasi berkisar usia di sekolah dasar; tahap tentative (12 - 18 tahun berkisar usia di sekolah menengah); tahap realisti (19- 25 tahun, berkisar usia di perguruan tinggi).

Manfaat Perencanaan Karir Hal penting dalam perencanaan karir inidividu yaitu perencanaan karir individual. Menurut Mathis dalam Ozora bahwa perencanaan karir individual adalah usaha yang dilakukan seseorang untuk mendapatkan kemajuan bagi dirinya. Pada level individu maka seseorang perlu mengenal diri lebih dalam dari sisi potensi dan kemampuannya. Individu akhirnya memegang kendali penuh dalam mengarahkan, mengendalikan dan mengambil keputusan yang berhubungan dengan karirnya. Adanya manfaat dari adanya perencanaan karir yaitu a. pengetahuan dan pemahaman diri sendiri akan meningkat; b. lebih tangap akan saat dihadapkan pada persoalan sehingga adanya keputusan yang efektif; c. memperoleh informasi akan karir yang lebih terarah; d. tanggap dalam memanfaatkan kapasitas yang ada sesuai dengan kemampuannya; e. membuat keragaman dalam dunia kerja pada angkatan kerja yang dimiliki.

Berdasarkan penelitian yang ada seperti yang dilakukan oleh Ozora dan rekan maka lebih banyak menyatakan faktor internal individu memegang peranan terhadap tercapai karir yang sukses. Seperti pada aspek mengenali potensi dan kesesuaian terhadap rencana karirnya, adanya minat terhadap karir tertentu. Pada akhirnya kemantapan kepribadian hingga kebutuhan kesejahteraan psikologi yang mantap menjadi dasar dari terpenuhinya perencanaan karir selanjutnya. Untuk itu model penguatan terhadap aspek internal dalam suatu perencanaan karir sangat dibutuhkan. Tidak sekedar memiliki kepercayaan diri yang kuat terhadap suatu bidang karir tertentu. Tetapi memiliki minat yang sesuai dengan karir yang direncanakan. Tidak memaksakan diri dalam mengambil bidang yang ada menjadi 
salah satu kunci keberhasilan. Hanya saja jika persoalan disebabkan dari kesulitannya seseorang bisa mengenali karakteristik dirinya maka mempengaruhi semua proses dalam perencanaan karirnya. Tugas Perguruan Tinggi untuk sejak dini mengenali karakteristik pribadi termasuk membebaskan dari problem laten yang menghambat dari seluruh sumber daya yang dimiliki agar mencapai hasil yang luar biasa. Yakni karakter tangguh sebagai capaian kompetensi lulusan. Hal tersebut sejalan dengan tujuan perguruan tinggi untuk dapat mengantarkan mahasiswanya mencapai sukses.

\subsection{Revolusi Industri 4.0 dalam unsur pembangunan SDM}

Indonesia saat ini mendukung adanya revolusi industry yang sedang berkembang ditengah perkembangan dunia. Revolusi industry 4.0 meupakan suatu moment yang mengubah tatanan kehidupan manusia termasuk dalam mengelola sumber daya manusia. Perubahan ini tentu sangat mempengaruhi adanya tuntutan kepada sumber daya manusia Indonesia dalam rangka memenuhi kompetensi yang unggul. Kemajuan dibidang teknologi dan infrastruktur saja tidak akan menjawab adanya kebutuhan yang saling melengkapi demi kesejahteraan manusia yang seharusnya dapat tercapai.

Penyiapan Sumber daya manusia ini di dalam kehidupan kampus juga turut berperan secara langsung yaitu dengan melakukan pengelolaan yang tepat terhadap input yang diperoleh. Mahasiswa menjadi pihak yang akan mendapatkan perhatian utama untuk dapat mengejar kebutuhan perubahan melalui revolusi industry 4.0. Dijelaskan bahwan kualitas SDM yang unggul tentu saja peril dipersiapkan untuk menyambut adanya perubahan. Kampus sebagai institusi pendidikan yang melahirkan generasi unggul perlu mendukung upaya persiapan tersebut. Dengan kualitas karakter tangguh harapannya lebih unggul dan berdampak pada kesiapan menghadapi revolusi industry 4.0.

\section{PEMBAHASAN}

Tantangan yang ada setelah memasuki revolusi industry 4.0 menjadi luar biasa dan terjadi peningkatan kompetisi lulusan perguruan tinggi yang semakin tinggi. Hal tersebut akan memicu suatu kompetisi di dunia industry dan pasar kerja pada umumnya. Kompetisi dapat terjadi antar perguruan tinggi hinggi kompetisi ditingkat individu. Tentu saja kompetisi yang diharapkan yaitu bersifat positif dan fair. Perubahan teknologi yang sangat pesat ternyata banyak memberikan kemudahan manusia. Karena disisi lain dengan memberikan segala kemudahan bagi generasi muda ternyata tidak membuat mereka semakin tangguh. Segala kondisi yang dapat dirasakan dan dilihat melalui perubahan sosial hingga pada perilaku SDM yang harus juga disadari oleh pemimpin perguruan tinggi. Tetapi mampu disadari dan dipahami dengan baik oleh generasi muda kita yaitu calon lulusan. Program yang sering ditawarkan kepada mahasiswa berupa seminar atau workshop sering kali dibutuhkan hanya untuk memenuhi angka kredit untuk memenuhi syarat kelulusan. Dengan demikian segala bentuk kegiatan dan program yang dimiliki oleh pusat karir tidak seolah-olah membangun kesadaran atas kebutuhan pengembangan diri danmeningkatkan kualitas generasi. Hal ini berguna mencapai suatu kompetensi yang diharapkan sebagai lulusan perguruan tinggi yang siap menjawab tantangan pasar kerja di era revolusi industry 4.0.

Pusat karir yang ditunjuk untuk melakukan pengeloaan diharapkan melakukan positioning yang mantap agar keberadaannya turut mencapai target yang diharapkan Dan pada akhirnya mampu mendapatkan dukungan dari berbagai pihak untuk bersama-sama mewujudkan lulusan yang berkarakter tangguh. Layanan Personal Development \& Care sebagai contoh bentuk pengembangan yang diusulkan dari unit pusat karir menjadi wadah yang memiliki fungsi utama dalam melayani kebutuhan psikologis mahasiswa. Layanan ini dibangun dalam rangka kepedulian kampus terhadap tingkat kesejahteraan psikologis dan mental mahasiswa dalam rangka mempersiapkan generasi dalam memasuki dunia kerja. 
Kampus pada akhirnya sebagai lingkungan akademis dapat menjadi model (Social Support System) yang kuat untuk mendorong segenap lulusan memiliki ketangguhan dalam menghadapi beragam tantangan mendatang. Mahasiswa perlu mendapatkan peningkatan individual wellness. Yaitu upaya meningkatkan kompetensi dan skill dalam membangun startegy coping yang adaptif dalam menghadapi beragam tantangan dalam dunia karir. Contoh: meningkatkan regulasi diri mahasiswa, problem solving, membangun empati, conflict interpersonal, dan seterusnya.

Dalam rangka membangun karakter tangguh maka perlu membangun promosi dan prevensi kesejahteraan psikologis pada tahap universal, yaitu melakukan berbagai kegiatan untuk membangun kesejahteraan psikologis yang berfokus pada lingkungan yang tidak tidak harus berisiko pada suatu permasalahan kesehatan mental. Sebagai aktivitas pendukung yaitu seminar dan workshop dengan tema pengembangan diri, manajemen stress, dsb; Sebagai layanan utama memberikan layanan Konsultasi membangun upaya prevensi pada tahap selected yaitu melakukan upaya pendekatan psikologis secara langsung kepada mahasiswa yang telah terdeteksi dini berisiko memiliki persoalan psikologi; dan memberikan fasilitas peer group discussion, yaitu memberikan kesempatan pada kelompok diskusi mahasiswa memecahkan suatu persoalan dengan latar belakang yang sama.

Untuk mendukung pengembangan layanan maka diperlukan adanya sistem IT sebagai salah satu tool yang membantu mekanisme pelayanan. Adanya kemudahan akses pelayanan program pengembangan diri ini disertai dengan pengembangan fitur berbasis IT. Hal ini akan mendorong keinginan orang untuk menyelesaikan persoalan dengan segera. Sehingga Mahasiswa lebih bebas dari persoalan laten yang terpendam dan kampus dapat memberikan fungsi model sistem support sosial yang lebih optimal. Maka ketahanan diri yang meningkat dan menghasilkan lulusan yang tangguh dan meningkatkan kompetensi lulusan dalam menghadapi pasar kerja.

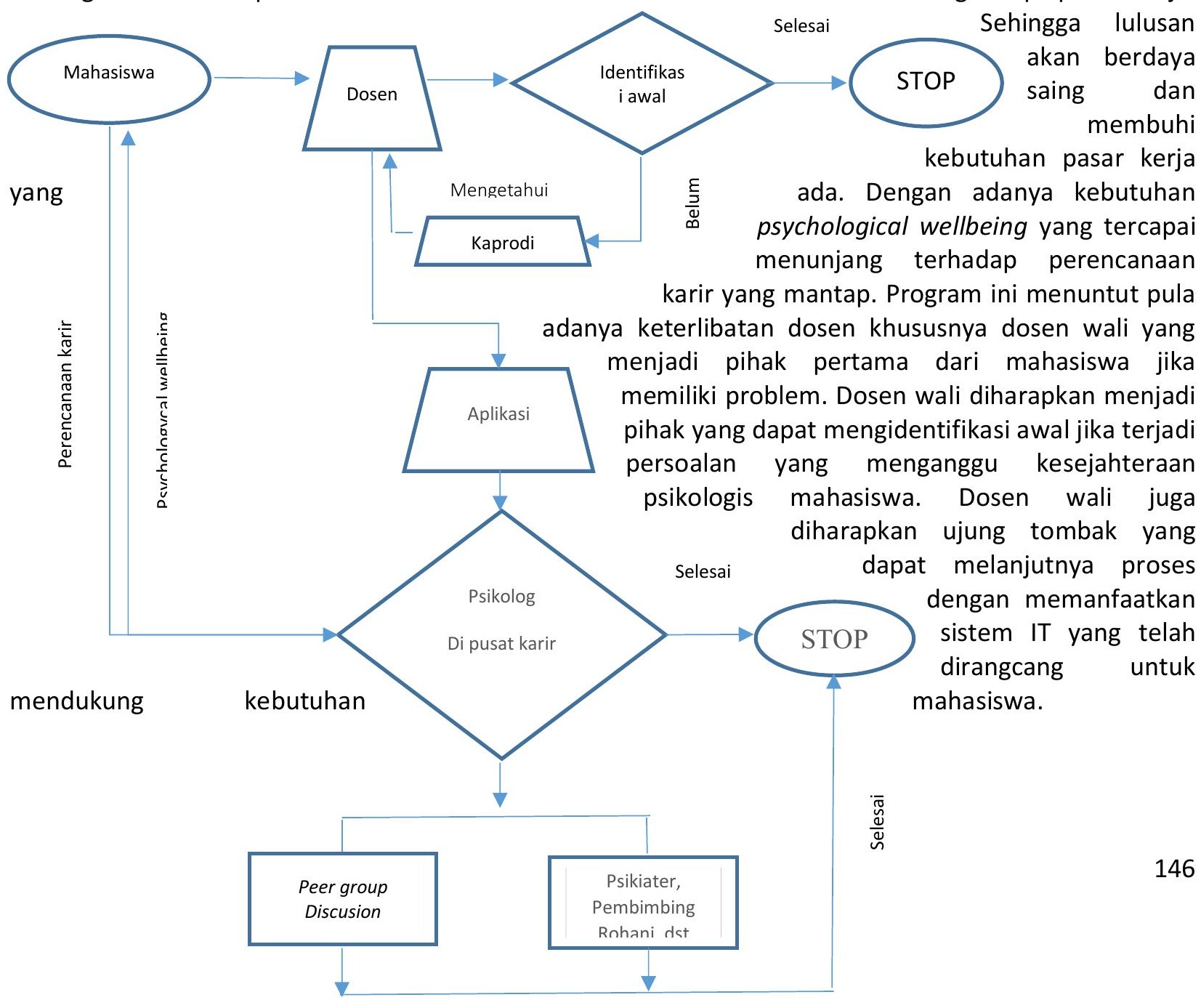


Diagram. 1. Model Pengembangan Layanan Karir Mahasiswa di Perguruan Tinggi

\section{PENUTUP}

\subsection{Kesimpulan}

Pengembangan layanan di pusat karir nampaknya perlu dilakukan seiring dengan upaya pemenuhan terhadap kebutuhan mahasiswa untuk mencapai kompetensi yang ditargetkan. Kompetensi yang berhubungan dengan corak karakteristik pribadi sangat terkait dengan kompetensi yang dibutuhkan dunia kerja. Mahasiswa yang seharusnya memiliki perencanaan karir yang mantap didukung oleh adanya corak karakter yang mantap. Desain pengembangan layanan ini dikhususkan untuk mendukung percepatan akses mahasiswa terhadap pihak-pihak yang turut menuntaskan adanya persoalan dari mahasiswa. Mengacu kepada kebutuhan akan karakter yang tangguh sebagai salah satu kompetensi yang harus dicapai oleh generasi baru sebagai lulusan menjadi perhatian utama atas perubahan revolusi indutri 4.0. Pusat karir sebagai unit yang diberikan tanggung jawab untuk melakukan pengelolaan terhadap SDM di kampus pada akhirnya perlu menangkap adanya kebutuhan atas perubaham di revolusi industry 4.0. 


\section{DAFTAR PUSTAKA}

Evans, T. M. (2017). Understanding the Career Game : Figuring Out "the Rules " of Career Planning and Getting Motivated to Plan for a Successful Career. ReSearch: A Career Guide for Scientists. Elsevier. https://doi.org/10.1016/B978-0-12-804297-7.00004-5

Ir. Ahmad Syafiq, MSc, P. ., Dr. Eng. Bambang Setia Budi, ST, M., Dr. Dyah Werdiningsih, Mp., Dr. Ir. Kusnandar, Ms., Parapat Gultom, P. ., Pipin Sukandi, SE, M., \& Fikawati, D. S. (2018). BUKU ACUAN PENGEMBANGAN PUSAT KARIR PERGURUAN TINGGI DI INDONESIA 11 Mei 2018. Jakarta: Kemenristekdikti. Belum diterbitkan.

Muhson, A., Wahyuni, D., \& Mulyani, E. (2012). ANALISIS RELEVANSI LULUSAN PERGURUAN TINGGI, 8(April).

Ozora, D., Suharti, L., \& Sirine, H. (2016). Potret Perencanaan Karir Pada Mahasiswa (Studi terhadap Mahasiswa di Sebuah Perguruan Tinggi di Jawa Tengah). Unisbank Semarang, 623-632.

Rogers, M. E., Creed, P. A., \& Glendon, A. I. (2008). The role of personality in adolescent career planning and exploration : A social cognitive perspective, 73, 132-142.

https://doi.org/10.1016/j.jvb.2008.02.002 